MARKETING AND BRANDING
RESEARCH $\begin{gathered}\text { INDUSTRIAL } \\ \text { MANAGEMENT } \\ \text { INSTITUTE }\end{gathered}$

\title{
Evaluating and comparing the ability to predict the bankruptcy prediction models of Zavgren and Springate in companies accepted in Tehran Stock Exchange
}

\author{
Ghodratollah Talebnia $^{1}$, Fatemeh Karmozi ${ }^{2 *}$, Samira Rahimi ${ }^{2}$ \\ ${ }^{1}$ Faculty Member of Islamic Azad University, Science and Research Branch \\ ${ }^{2} \mathrm{PhD}$ Student of Accountancy, Islamic Azad University, Bandarabbas Branch
}

\begin{tabular}{ll}
\hline & ABSTRACT \\
\cline { 2 - 3 } & Recent bankruptcy of large companies at international level and volatilities of securities in \\
Keywords: & $\begin{array}{l}\text { Iran have highlighted the necessity of evaluating the financial power of companies. One of } \\
\text { the evaluating tools is using bankruptcy prediction models. Bankruptcy prediction models are } \\
\text { Bankruptcy Models } \\
\text { one of the tools for estimating the future condition of companies. The aim of this research is } \\
\text { to present theoretical foundations and compare the results of investigating two models of } \\
\text { Zavgren (1985) and Springate (1978) in Iran's exchange market through main and adjusted } \\
\text { coefficients according to statistical techniques of Logit and Multiple Discriminant Analysis } \\
\text { (MDA). The data was gathered and tested from 2009 to 2013. The results indicated that the } \\
\text { adjusted Springate Model was more efficient than other models in the bankruptcy year. }\end{array}$
\end{tabular}

(C)AIMI Journals

\section{Introduction}

Bankruptcy is one of the issues, which is not expected by any of the users of financial statements; however, they are always concerned about it (Hajiha, 2004). Bankruptcy has major effects on management, shareholders, employees, creditors, customers, and other beneficiaries, thus it challenges the country socially and economically (Altman, 1968).

Adopting the appropriate strategy requires getting information, processing and analyzing the information, and concluding logically from the information, which is known as financial analysis in financial literature. Obviously, high information on an issue leads to more precise analysis and conclusion. Bankruptcy is considered as an important issue in financial management. Investigating the reasons of bankruptcy, evaluating it through financial and 
accounting foundations, analyzing financial ratios, and studying the common bankruptcy models are of great importance (Rahnamai Roudposhti, Nikoomaram, \& Shahvardiani, 2011).

Bankruptcy prediction models are one of the tools for estimating the future condition of companies. Investors and creditors have the highest tendency to predict bankruptcy, because in case of it, they must incur high costs. In this research, it is attempted to compare four models of bankruptcy, calculate their ratios, and compare the results of performing them with the real conditions of studied companies, so that the abilities of these models can be determined.

Due to the increasing development of financial and investing markets, fierce competition in business, industry, and investment was launched. Immediate reaction to the condition of market plays a crucial role in business status. Discovering operational and financial problems of the companies is accompanied by the analysis of financial ratios and financial ratios are one of the important tools of evaluating companies for the investors and managers of the unit, so that they can predict the future condition (Rahnamai Roudposhti, Alikhani, \& Maranjouri, 2009).

In financial decision-making on an institution, scientific and authentic indices are needed. One of the appropriate indices for this aim is the accurate evaluation of company bankruptcy risk. Analyzing financial ratios is one of the important tools for predicting company bankruptcy and the models based on these analyses can be used to achieve this goal.

In Tehran Stock Exchange, some companies have been successful and some have been unsuccessful. In unsuccessful companies, investors always attempt to find a solution to facilitate appropriate decision-making. In the present study, it has been tried to present two models of bankruptcy in Tehran Stock Exchange and compare these models and their efficiency in this market.

Developing bankruptcy prediction models has been considered as an important and wide issue in academic community and business long ago. Predicting bankruptcy can have a considerable impact on lending and profiting decisions made by financial institutions (Shin, Lee, \& Kim, 2005).

The aim of this research is to find a model to investigate and predict company bankruptcy before it occurs, so that through appropriate and punctual strategies and decisions, business crisis and failure can be averted. Moreover, according to the prediction models of other countries, it is attempted to design a model based on the condition of Iran's exchange market, so that its ability to evaluate company bankruptcy prediction can be investigated and decision-makers and beneficiaries of financial information can make appropriate and punctual decisions.

\section{The Literature Review}

Alkhatib and Al Bzour (2011) investigated the data from 1990 to 2006 through calculating financial ratios and using the models of Altman (1968) and Kida (1998). The results indicated that Altman's model had an advantage in company bankruptcy prediction with a 93.8\% average predictive ability while the average for Kida’s model was 69\%.

Kiyak and Labanauskaite (2012) investigated the relationship between financial ratios and bankruptcy prediction according to the models of Altman (1968), Springate (1978), Zavgren 
(1985) and Chesser (1974). In order to test the research hypothesis and calculate financial ratios, they collected data from companies in Lithuania from 2006 to 2010. They analyzed the mentioned models through the data and concluded that there was no effective relationship between the Logit analysis of Zavgren and bankruptcy. However, the multiple model of Altman had a high ability to predict bankruptcy.

\section{Research Hypotheses}

The following hypotheses guided the study:

$\mathrm{H}_{1}$ : The models of bankruptcy prediction are able to categorize bankrupt and solvent companies correctly.

$\mathrm{H}_{2}$ : The adjusted models of bankruptcy are able to categorize bankrupt and solvent companies correctly.

$\mathrm{H}_{3}$ : There is a significant difference between the main coefficients of models and the adjusted model in terms of prediction.

\section{Method}

The present study is an applied research adopting a descriptive method. In these kinds of researches, the principles, abilities, and techniques of researches are used to solve executive and authentic issues. This research is also correlational in terms of data collection. This study has two separate executive stages:

Stage one: Since the aim of this research is to evaluate the continuity of companies through the mentioned models and the coefficients of these models have been calculated in the economic and commercial conditions of non-Iranian companies, first, the efficiency of these models in Iranian companies must be tested.

Stage two: After testing the efficiency of these models, this research attempts to adjust the coefficients of variables in the models. In other words, the coefficients of variables must be adjusted according to the commercial structure and condition of Iranian companies. Therefore, through the data of sample companies and applying appropriate statistical methods, the coefficients of models will be adjusted.

The statistical population of this research includes the companies accepted in Tehran Stock Exchange. To select the sample, the companies accepted in Tehran Stock Exchange must contain the following items: Their information must not be incomplete or defaced and they must not be banks or other financial intermediaries. During the research, their financial statements must be presented to the organization. Regarding these items, 362 companies were selected as sample.

The statistical population is divided into two groups of bankrupt companies and solvent companies. Since the number of members in the population is small, all the members are included and bankrupt companies are selected according to the business rules without considering the type of industry. The criterion for selecting bankrupt companies is the article 141, amendatory bill of business rules. The number of bankrupt companies according to the mentioned category is 40 which all of them have been bankrupted in the selected years. The 
three-year period, which ends in the year bankruptcy occurred, was considered as the foundation of the study.

After selecting the sample of bankrupt companies, those companies which had not suffered a loss in the mentioned period, were separated. Afterwards, among these companies, the ones with higher average of profits in these five years were considered as solvent companies and equal to the number of bankrupt companies, the most solvent companies were selected as the sample. Then, the most successful three years were considered as the studied years. In both types of samples, there are companies from different industries, however, there is no definite parallelism, and thus it has been considered as an uncontrollable variable.

The data has been collected through library method to study the theoretical foundations, literature, and background of the research. Moreover, different tools have been conducted like Excel spreadsheet software. In the current research, in order to analyze the data and test the hypotheses, SPSS software has been applied.

The variable of this study are categorized into two groups according to their role: Independent variables and dependent variables. Independent variables in this research are financial statements. Since four models have been used, they are mentioned in order:

1. $y=0.23883-0,108 x l-1.583 x 2-10.78 x 3+3.074 x 4+0.486 x 5-4.35 x 6-0.11 \times 7$

$\mathrm{x} 1=$ selling/ average stocks

$\mathrm{x} 2=$ accounts receivable average/ average stocks

$\mathrm{x} 3=$ short-term investment + cash/ total assets

$\mathrm{x} 4=$ quick assets/ current debts

$\mathrm{x} 5=$ operating profit - total asset/ current debt

$\mathrm{x} 6=$ long-term debt - total asset/ current debt

$\mathrm{x} 7=$ selling/ fixed assets + net working capital

bankruptcy risk $=1.1+\mathrm{e}^{-\mathrm{y}}$

To calculate the bankruptcy risk of every company, which is a unique number, y must be put in the above formula. The output of the model, which is the bankruptcy risk of related company, ranges from zero to one. The larger this number is and closer to one, the more bankruptcy risk will be and the smaller this number is and closer to zero, it will show less bankruptcy risk (Gibson, 2008).

2. Springate model:

$S=1.03 \times 1+3.07 \times 2+0.66 \times 3+0.4 \times 4$

$\mathrm{x} 1=$ working capital divided by total assets

$\mathrm{x} 2=$ earnings before interest and taxes divided by total assets

x3= earnings before taxes divided by current debt

$\mathrm{x} 4=$ selling divided by total assets

If $\mathrm{S}<=0.826$, the company is bankrupted. 
The models, which have been adjusted and are considered as new independent variables are as following:

3. The adjusted model of Zavgren:

$Y=-3.289-7.819 x 3+4.871 x 4-13.314 x 6-0.585 x$

4. The adjusted model of Springate

$\mathrm{S}=2.47 \mathrm{x} 1+0.24 \times 3$

The variables of this model are based on the initial model. In this research, there is one dependent variable, which is of two kinds, namely the companies in terms of financial ability that whether they are bankrupt or solvent.

In order to analyze the data, due to their nature, there are various ways and the researchers must pay attention to their application, so that they can reach precise conclusions (Delavar, 1997). Table 1 shows the results based on based model.

Table 1

Results based on Base Model (Initial)

\begin{tabular}{lccc}
\hline \multirow{2}{*}{ Model } & \multicolumn{2}{c}{ The Studied year } & \\
\cline { 2 - 4 } & The Bankruptcy Year & A Year before Bankruptcy & Two Years before Bankruptcy \\
\hline Springate Model & 88 & 69 & 55 \\
\hline Zavgren Model & 60 & 70 & 42 \\
\hline
\end{tabular}

Testing the first hypothesis indicates that the bankruptcy prediction models have the ability to predict the bankruptcy. In summary, the results of testing two models and the comparison between them are presented in Table 2.

Table 2

Comparing the Results of Testing the Models

For the Bankruptcy Year: The Ability to Predict the Model of Springate > The Ability to Predict the Model of Zavgren

For a Year before Bankruptcy: The Ability to Predict the Model of Springate > The Ability to Predict the Model of Zavgren

For Two Years before Bankruptcy: The Ability to Predict the Model of Springate > The Ability to Ppredict the Mmodel of Zavgren

Table 3 presents the results based on adjusted model.

Table 3

Results based on Adjusted Model (Proposed Model)

\begin{tabular}{lccc}
\hline \multirow{2}{*}{ Model } & \multicolumn{2}{l}{ The Studied Year } & \\
\cline { 2 - 4 } & The Bankruptcy Year & A Year before Bankruptcy & Two Years before Bankruptcy \\
\hline Springate Model & 75 & 63 & 66 \\
\hline Zavgren Model & 58 & 46 & 52 \\
\hline
\end{tabular}


In order to investigate the significant relationship between the models of prediction, Kruskal-Wallis Test has been used. All the statistical analyses have been conducted through SPSS software.

Table 4

Comparing the Results of Testing the Adjusted Models

For the Bankruptcy Year: The Ability to Predict the Adjusted Model of Springate > The Ability to Predict the Model of Zavgren

For a Year before Bankruptcy: The Ability to Predict the Adjusted Model of Zavgren> The Ability to Predict the Model of Springate

For Two Years before Bankruptcy: The Aability to Predict the Adjusted Model of Springate > The Ability to Predict the Model of Zavgren

Testing the second hypothesis indicates that the bankruptcy prediction models, which have been adjusted through the statistical methods of MDA and Logit, have the ability to predict the bankruptcy. In summary, the results of testing the four adjusted models and the comparison between them are presented in Table 4.

\section{Discussion and Conclusion}

Bankruptcy is considered as an important issue in financial management and the aim of this research was to find a model to investigate and predict company bankruptcy before it occurs, so that through appropriate and punctual strategies and decisions, business crisis and failure can be averted. Moreover, according to the prediction models of other countries, it was attempted to design a model based on the condition of Iran's exchange market, so that its ability to evaluate company bankruptcy prediction can be investigated and decision-makers and beneficiaries of financial information can make appropriate and punctual decisions. According to the results of this study, the adjusted Springate Model was more efficient than other models in the bankruptcy year.

It is recommended that the models in this research come into use to predict the companies' bankruptcy and their results be applied to decision-making in the exchange market. Moreover, other methods can be used to adjust the prediction models and retest their results. Finally, it is also recommended that these models should be developed and retested in later years, so that the results will be more reliable.

\section{References}

Alkhatib, K., \& Al Bzour, A. E. (2011). Predicting corporate bankruptcy of Jordanian listed companies: Using Altman and Kida models. International Journal of Business \& Management, 6(3), 208-215.

Altman, E. I. (1968). Financial ratios, discriminant analysis and the prediction of corporate bankruptcy. The Journal of Finance, 23(4), 589-609.

Chesser, D. L. (1974). Predicting loan noncompliance. The Journal of Commercial Bank Lending, 56(8), $28-38$.

Delavar, A. (1997). Theoretical and science-research foundations in human and social sciences. Tehran, Iran: Adib Publication.

Gibson, C. H. (2008). Financial reporting and analysis: Using financial accounting information (13 ${ }^{\text {th }}$ ed.). Boston, USA: Cengage Learning.

Hajiha, Z. (2004). Presenting the model of predicting the power of debts payment in manufacturing companies in Tehran Stock Exchange (Unpublished master's thesis). Alzahra University, Iran.

Kida, C. Y. (1998). Financial ratios as predictors of bankruptcy in Japan: An empirical research. Journal of Finance, 123, 589-609. 
Kiyak, D., \& Labanauskaite, D. (2012). Assessment of the practical application of corporate bankruptcy prediction models. Economics \& Management, 17(3), 895-905.

Rahnamai Roudposhti, F., Alikhani, R., \& Maranjouri, M. (2009). Investigating the application of bankruptcy prediction models of Altman and Fulmer in companies accepted in Tehran Stock Exchange. The Iranian Accounting \& Auditing Review, 16(55), 19-34.

Rahnamai Roudposhti, F., Nikoomaram, H., \& Shahvardiani, S. (2011). Strategic financial management. Tehran, Iran: Hakimbashi Publication.

Shin, K. S., Lee, T. S., \& Kim, H. (2005). An application of support vector machines in bankruptcy prediction model. Expert Systems with Application, 28(1), 127-135.

Springate, G. L. V. (1978). Predicting the possibility of failure in a Canadian firm (Unpublished master's thesis). Simon Fraser University, Canada.

Zavgren, C. (1985). Assessing the vulnerability to failure of American industrial firms: A logistic analysis. Journal of Business Finance \& Accounting, 12(1), 19-45. 